\title{
GEOGRAFSKI VIDIKI POPLAV V SLOVENIJI
}

\author{
Blaž Komac, Karel Natek, Matija Zorn: Geografski \\ vidiki poplav v Sloveniji. Zbirka Geografija Slovenije 20. \\ Založba ZRC, 180 str. Ljubljana 2008.
}

Knjiga, ki je leta 2008 izšla pri Založbi ZRC, je že dvajseta iz zbirke Geografija Slovenije in predstavlja pomemben prispevek k razumevanju poplav v slovenskih pokrajinah. Trije avtorji so se problematike lotili s podrobno analizo poplavnih značilnosti. V prvem delu knjige je poudarek na vzrokih in

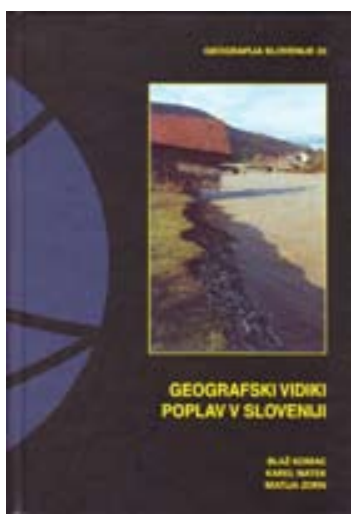
vrstah poplav, ki pomembno zaznamujejo slovenske pokrajine, saj pokrajinska pestrost Slovenije odločilno vpliva na njihovo pogostnost in vrsto. Ponekod, npr. v fluvialnem reliefu predalpskega hribovja so v ospredju hudourniške poplave, ki imajo povsem drugačne značilnosti kot poplave na kraških poljih, ali pa denimo nižinske poplave ob spodnjem toku Krke ali Sotle.

Pri razumevanju razsežnosti poplav je odnos družbe do tega hidrološkega pojava zelo pomemben, le-ta pa se kaže tudi skozi veljavno zakonodajo na področju gospodarjenja $\mathrm{z}$ rekami in njihovimi porečji. Knjiga se v nadaljevanju posveti tako domači zakonodaji kot zakonodaji nekaterih drugih evropskih držav na področju poplavne varnosti in tako nazorno pokaže razlike in podobnosti pri obravnavanju tega naravnega pojava. Pomemben del knjige je zemljevid poplavne ogroženosti Slovenije, poglavje pa vsebuje tudi manjše izseke območij ter grafične priloge, ki prispevajo k boljšemu razumevanju poplav in njihovih posledic.

Najobsežnejše poglavje obsega geografske značilnosti poplavnih območij v Sloveniji, ki jih avtorji obravnavajo po porečjih ali delih porečij, vključno z morskimi poplavami. V zadnjem vsebinskem poglavju se knjiga posveti tudi umetnim in naravnim pregradam kot dejavniku, ki vpliva na obseg in intenziteto poplav.

Vsebina knjige je pestra, saj obravnava poplave v širokem spektru naravnih in družbenih dejavnikov. Pestrost pa poleg vsebinsko zanimivih in smiselno umeščenih poglavij dopolnjujejo številne fotografije, preglednice in grafikoni, tako da je skoraj na vsaki strani besedilo prekinjeno s katerim od omenjenih elementov, kar pri bralcu poveča pozornost in omogoča lažje razumevanje vsebine. Na 180 straneh najdemo kar 126 slik, večinoma fotografij, pa tudi kart v barvnih in črnobelih odtenkih, kar je pomembna kakovost knjige, saj fotografije poplav ali njenih posledic pogosto povedo več kot še tako podrobno napisano besedilo. Najstarejše fotografije segajo v 20. leta prejšnjega stoletja in bralcu približajo poplave iz časov, ko so bile fotografije prej redkost kot pravilo. Ravno iz tistega časa pa poznamo izredno povodenj, ki tudi danes nenehno opozarja na poplavno ogroženost slovenske prestolnice. Knjiga vsebuje tudi 16 preglednic in obsežen seznam virov in literature, ki vsebuje preko 300 domačih in tujih enot, kar kaže, da so avtorji temeljito preučili obsežno literaturo in ta spoznanja s svojim empiričnim delom sestavili v strokovno in berljivo celoto, ki v slovenski geografski literaturi zapolnjuje pomembno vrzel. Knjiga je lahko uporabno gradivo tako študentom kot 
strokovnjakom s področja prostorskih ved, geografom, vodarjem, krajinskim arhitektom, gradbenikom, arhitektom, urbanistom in drugim. Nazoren prikaz z veliko fotografijami in preglednicami pa vsebino približa tudi laičnim bralcem, s čimer se krog uporabnikov knjige precej razširi.

Matej Ogrin 